\title{
Expansion of Irrigation Area Due to the Extreme Rainfall
}

\author{
Rusdi Efendi, Lily Montarcih Limantara, Widandi Soetopo, and Ery Suhartanto
}

\begin{abstract}
This research intends to expand the irrigation area by taking advantages of extreme rainfall. The methodology consists of determining the consumptive use of crop, rainfall day and the probability of event, rainfall that is used for cropping, consumptive use of crop when there is happened the extreme rainfall on climate anomaly, and cropping area. To be believed that rainfall that is dropped when positive SOI and negative dipole on climate anomaly will be more than the general rainfall on the same month. The rainfall that is dropped in the catchment area gives the effect to the reservoir inflow and that is dropped in the agricultural area will give the effect to the irrigation water supply. The result shows that the difference between water demand in the normal year and in the climate anomaly period can be used to expand the cropping area.
\end{abstract}

Keywords : irrigation cropping area, extreme rainfall, consumptive use of crop, climate anomaly.

\section{INTRODUCTION}

The natural condition change in the upstream as well as in the downstream of dam causes the new operation pattern of reservoir or dam and it is felt as an effort that has to be carried out. The initial operation pattern that has the function to reduce flood only due to the inundation space over the spillway elevation becomes to give additional space [1] will be more and has to give priority the irrigation function through the regulation of the available water in the storage. If it is seen from the period, dam or reservoir more help in irrigation water availability on the dry season, however for the aim to reduce flood is more happened on the rainy season [2][3].

In a dam, if it is seen from the water that is stored for irrigation, it has to be available the storage as much as possible; however for the aim of flood control, the storage has to be less so it can hold the more flood.

Revised Manuscript Received on December 30, 2019.

* Correspondence Author

Rusdi Efendi, Doctoral Program in Department of Civil Engineering, Faculty of Engineering, University of Brawijaya, Malang, Indonesia.

Lily Montarcih Limantara* Department of Water Resources, Faculty of Engineering, University of Brawijaya, Malang, Indonesia.

Widandi Soetopo, Department of Water Resources, Faculty of Engineering, University of Brawijaya, Malang, Indonesia.

Ery Suhartanto, Department of Water Resources, Faculty of Engineering, University of Brawijaya, Malang, Indonesia.

(C) The Authors. Published by Blue Eyes Intelligence Engineering and Sciences Publication (BEIESP). This is an open access article under the CC-BY-NC-ND license http://creativecommons.org/licenses/by-nc-nd/4.0/
The aim of irrigation water supply and flood reduction is on the contrary to each other, so to operate the irrigation dam in order to fulfill the both aims, it is needed the accuracy in estimating the amount of discharge and the happened time [4], therefore the reservoir is conditioned to be able to fulfill the irrigation water demand and also can hold the flood Song et,al. [5] explained that remembering that the increasing of water demand and the limitation of the new water resources development, so the evolution of reservoir function from single to the plural objectives is necessary to be considered. The result of his research expressed to determine the variety of irrigation efficiency is needed to be further investigated and the operation pattern is suggested to consider the various irrigation efficiency and the food control will give the more benefit however it has the possibility of significant estimation error in giving the irrigation water supply, the emergency release spillway, and the main spillway release. Ahmadi et.al. [6] said that to apply the dynamic real time of reservoir operation pattern will become as the effective adaptation approach to the climate change. In this study, it is known that due to the climate change gives the impact to the decreasing of discharge and it is produced the better reservoir reliability if the reservoir operation pattern is more adaptive than the previous pattern. Hai et.al [7] expressed that the climate change did not only influence the yearly total discharge volume, but it will also change the monthly distribution pattern in a year and it will more happen the flood peak [8] The real time of reservoir operation pattern can give the high reliability in protecting the drought and flood control. It is different with Eum et.al. [9] who expressed that the climate change and reservoir operation can be back optimized by considering the climate condition change. The result os this study showed that the damage due to the flood can be decreased by the reservoir operation that is developed for some scenarios of climate change. Purwandaru [10] has carried out his study in East Java and expressed that the La-Nina caused the increasing of rainfall on rainy season as well as dry season. La-Nina also caused the moving or change of the long or short rainy and dry season that caused the change of cropping pattern, cropping area, harvesting area, main food production, and automatically the food productivity. The researches above except the Purwandaru one, expressed that the real time of reservoir operation pattern will give big benefit in facing the climate change, however if the climate change is seen from the risk side, the reservoir operation that is developed is to be able to reduce flood without an effort to increase the main function. However Purwandaru [10] saw the La-Nina can change the cropping area.

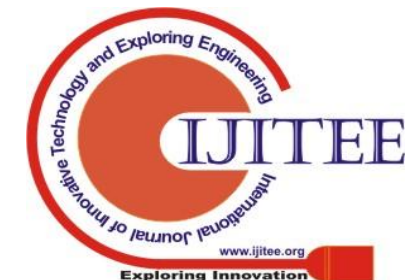




\section{Expansion of Irrigation Area Due to the Extreme Rainfall}

Therefore, this research intends to expand the irrigation crop area by taking advantage of extreme rainfall due to the climate anomaly. flooding area that experienced the yearly flood risk, This research is conducted in the Way Rarem Dam, Map of location is presented as in the Fig. 1

\section{MATERIAL AND METHOD}

\section{A.Research Location}

This study is carried out in yearly reservoir or dam which the main function is irrigation and in the downstream there is

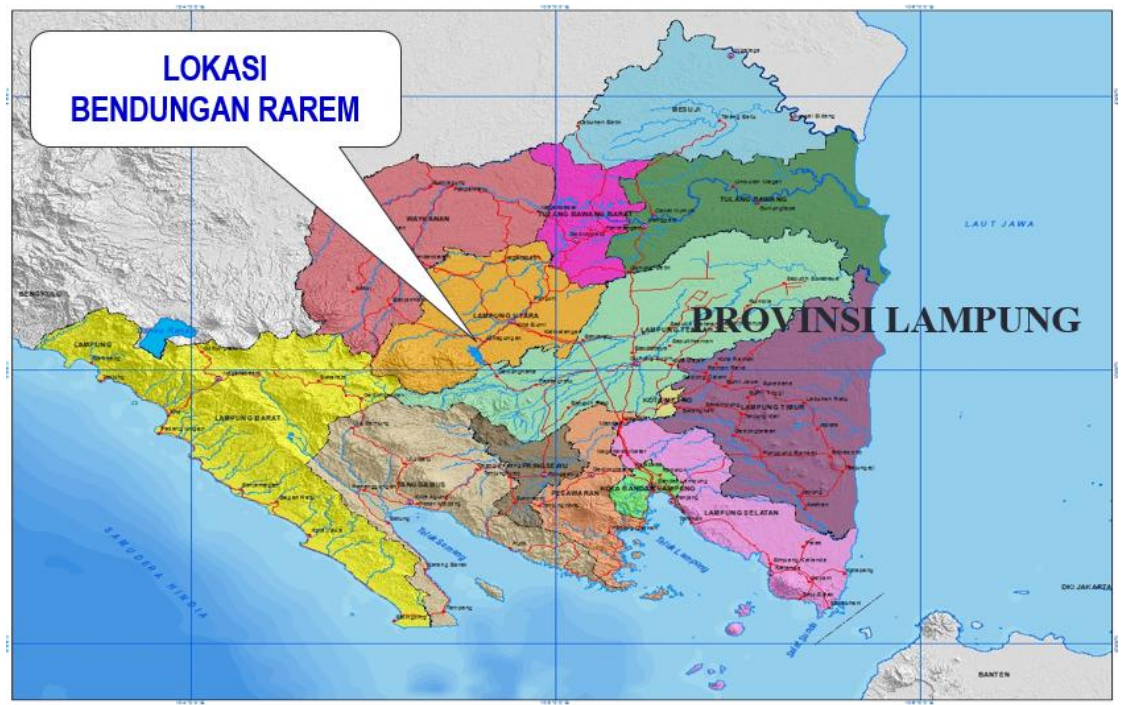

Fig, 1 The location of Way Rarem dam

\section{B. Consumptive use of crop}

Water demand in the rice fields for paddy is determined by some factors that are land preparation, consumptive use, percolation and seepage, water layer change, and effective rainfall. Generally the water demand is formulated as follow [11][12][13]:

$\mathrm{NFR}=\mathrm{ETC}+\mathrm{P}-\mathrm{R}_{\mathrm{eff}}+\mathrm{WLR}$

Where:

$\mathrm{NFR}$ = fresh water demand in rice fields (mm/day)

ETc = potential evapotranspiration ( $\mathrm{mm} /$ day)

$\mathrm{P} \quad=$ percolation $(\mathrm{mm} /$ day $)$

$\mathrm{R}_{\text {eff }} \quad$ = effective rainfall ( $\mathrm{mm} /$ day)

WLR = water layer change $(\mathrm{mm} /$ day $)$

Because of the effective rainfall $\left(R_{\text {eff }}\right)$ is too small, so it can be ignored, so the consumptive use of crop when the climate anomaly is happened can be formulated as follow:

$$
\mathrm{NFR}_{\text {An }}=\mathrm{NFR}-\mathrm{R}_{\text {An }} \text {. }
$$

Where:

$\mathrm{NFR}_{\mathrm{An}}=$ fresh water demand in rice fields when climate anomaly (mm/day)

NFR = fresh water demand in rice field when design (mm/day)

$\mathrm{R}_{\mathrm{An}} \quad=$ rainfall when climate anomaly (mm/day)

\section{Rainfall day and the possibility of event}

The amount of rainfall day in a month may be event in 1 day, 2 days, or 3 days, and so on until 30 days. One rainfall day may be happened on the first, second, or third abd so on until $30^{\text {th }}$, it means that 1 rainfall day has the possibility of event 30 times. However, 2 rainfall days may be happened on the first and second, first and third, first and fourth and so on until $29^{\text {th }}$ or $30^{\text {th }}$, therefore 2 rainfall days has the possibility of event on
435 events. By the same way, 3 rainfall days has the possibility of event on 4060 events.

\section{Rainfall depth and the possibility of event}

If there is happened 1 rainfall day in a month, so it can be confirmed that the rainfall depth on this day is the same as the monthly rainfall. Remembering that the rainfall on the climate anomaly is big enough, so if there is happened 2 rainfall days on that month, so the possibility of the happened rainfall is as follow:

- 2 rainfall days > consumptive use of crop or

- 1 rainfall day $>$ consumptive use of crop and 1 day < consumptive use of crop

The possibility of rainfall depth event for $n$ days on the monthly rainfall condition $\geq 30$ times of consumptive use of crop is as follow:

$\mathrm{K}_{\mathrm{ch}}=(\mathrm{n}-1) \mathrm{q}-(\mathrm{n}-2)$

Where:

$\mathrm{K}_{\mathrm{cb}}$ = the possibility of rainfall depth event for $\mathrm{n}$ rainfall days

$\mathrm{N}=$ rainfall days $(\mathrm{n}=2 \ldots \ldots .30)$

$\mathrm{Q}$ = consumptive use of crop in rice fields

If $\mathrm{p}$ times of consumptive use of crop $\leq$ monthly rainfall $\leq((\mathrm{P}+1)$ times of consumptive use of crop, so the possibility of rainfall event for $\mathrm{n}$ rainfall days is as follow:

$\mathrm{K}_{\mathrm{ch}}=(\mathrm{n}-1) \mathrm{q}-(\mathrm{n}-2)$

Where:

$\mathrm{K}_{\mathrm{ch}}=$ the possibility of rainfall depth event for $\mathrm{n}$ rainfall days

$\mathrm{N}=$ rainfall day $(\mathrm{n}=2 \ldots . \mathrm{P})$

$\mathrm{Q}$ = consumptive use of crop in rice fields

For $\mathrm{n}=(\mathrm{P}+1)$

$\mathbf{K}_{\mathbf{c h}}=\mathrm{CH}_{\mathrm{Bln}}-\mathrm{q}-(\mathrm{n}-2)$ 
Where:

$\mathrm{K}_{\mathrm{ch}}=$ the possibility of rainfall depth event for $\mathrm{N}=\mathrm{P}+1$ $\mathrm{n}$ = rainfall day $(\mathrm{n}=\mathrm{P}+1$ until 30$)$

\section{RESULTS AND DISCUSSION}

\section{A. Rainfall day and the possibility of event}

Not all of the rainfall that are dropped in agricultural area can be used by the crop. If the rainfall that is dropped is more than the consumptive use of crop in rice fields, so the surplus of water is not used. The amount of rainfall that can be used by the crop every month is very affected by the rainfall days and the daily rainfall. To obtain the possibility of amount from the rainfall day is carried out as in the Table- I and II.

Table- I. Rainfall event date (2 rainfall day in 1 month)

\begin{tabular}{|c|c|c|c|c|c|c|c|c|c|c|c|c|c|c|c|c|}
\hline & \multicolumn{3}{|c|}{ Date } & \multicolumn{3}{|c|}{ Date } & \multicolumn{3}{|c|}{ Date } & & \multicolumn{3}{|c|}{ Date } & \multicolumn{3}{|c|}{ Date } \\
\hline & 1 & and & 2 & 2 & and & 3 & 3 & and & 4 & ............... & 28 & and & 29 & 29 & dan & 30 \\
\hline & 1 & and & 3 & 2 & and & 4 & 3 & and & 5 & & 28 & and & 30 & & & \\
\hline & 1 & and & 4 & 2 & and & 5 & 3 & and & 6 & & & & & & & \\
\hline & 1 & and & 5 & 2 & and & 6 & 3 & and & 7 & & & & & & & \\
\hline & 1 & and & 6 & 2 & and & 7 & 3 & and & 8 & & & & & & & \\
\hline & 1 & and & 7 & 2 & and & 8 & 3 & and & 9 & & & & & & & \\
\hline & 1 & and & 8 & 2 & and & 9 & 3 & and & 10 & & & & & & & \\
\hline & 1 & and & 9 & 2 & and & 10 & 3 & and & 11 & & & & & & & \\
\hline & 1 & and & 10 & 2 & and & 11 & 3 & and & 12 & & & & & & & \\
\hline & 1 & and & 11 & 2 & and & 12 & 3 & and & 13 & & & & & & & \\
\hline & . & & & & & & & & & & & & & & & \\
\hline & . & & & & & & & & & & & & & & & \\
\hline &. & & & & & & & & & & & & & & & \\
\hline & 1 & and & 28 & 2 & and & 29 & 3 & and & 30 & & & & & & & \\
\hline & 1 & and & 29 & 2 & and & 30 & & & & & & & & & & \\
\hline & 1 & and & 30 & & & & & & & & & & & & & \\
\hline The amo & unt & f event & 29 & & & 28 & & & 27 & 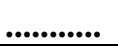 & & & 2 & & & 1 \\
\hline & & & & & & & & & & & & Tote & & & & 435 \\
\hline
\end{tabular}

Table - II. Rainfall event date (3 rainfall days in a month)

\begin{tabular}{|c|c|c|c|c|c|c|c|c|c|c|c|c|c|}
\hline & \multicolumn{3}{|c|}{ date } & \multicolumn{3}{|c|}{ date } & & \multicolumn{3}{|c|}{ date } & \multicolumn{3}{|c|}{ date } \\
\hline & 1,2 & and & 3 & 2,3 & and & 4 & ........... & 27,28 & and & 29 & 28,29 & and & 30 \\
\hline & 1,2 & and & 4 & 2,3 & and & 5 & & 27,28 & and & 30 & & & \\
\hline & & & . & & & . & & & & & & & \\
\hline & & & . & & & . & & & & & & & \\
\hline & & & . & & & . & & & & & & & \\
\hline & 1,2 & and & 29 & 2,3 & and & 29 & & & & & & & \\
\hline & 1,2 & and & 30 & 2,3 & and & 30 & & & & & & & \\
\hline & . & & & . & & & & & & & & & \\
\hline & . & & & . & & & & & & & & & \\
\hline & • & & & . & & & & & & & & & \\
\hline & . & & & . & & & & & & & & & \\
\hline & . & & & . & & & & & & & & & \\
\hline & $\cdot$ & & & . & & & & & & & & & \\
\hline & . & & & 2,28 & and & 29 & & & & & & & \\
\hline & 1,28 & and & 29 & 2,28 & and & 30 & & & & & & & \\
\hline & 1,28 & and & 30 & 2,29 & and & 30 & & & & & & & \\
\hline & 1,29 & and & 30 & & & & & & & & & & \\
\hline The & amoun & ent & 406 & & & 378 & ............. & & & 2 & & & 1 \\
\hline & & & & & & & & & Total & & & & 060 \\
\hline
\end{tabular}




\section{Expansion of Irrigation Area Due to the Extreme Rainfall}

The possibility of 435 for 2 rainfalls becomes as $30 \times 29 / 2=$ 435

The possibility of 4060 for 3 days becomes as $30 \times 29 / 2 \times$ $28 / 3=4,060$ or $435 \times 28 / 3=4,060$

For 4 rainfall days becomes as 4,060 x 27/4 = 27,405

For 5 rainfall days becomes as 27,405 x 26/5 = 142,506 or 6 rainfall days becomes as 142,506 x 25/6 = 593,775

Table- III presents the possibility amount of event from 1 until 30 rainfall days, the amount is 1,073,741,823 possibilities. Table - IV presents the amount of rainfall days and the possibility of event

Table- III. The amount of rainfall days and the possibility of event

\begin{tabular}{|c|c|c|c|c|c|}
\hline $\begin{array}{l}\text { Rainfall day } \\
\text { in a month }\end{array}$ & $\begin{array}{c}\text { The possibility } \\
\text { of event }\end{array}$ & $\begin{array}{c}\text { Rainfall } \\
\text { day in a } \\
\text { month }\end{array}$ & $\begin{array}{c}\text { The possibility } \\
\text { of event }\end{array}$ & $\begin{array}{l}\text { Rainfall } \\
\text { day in a } \\
\text { month }\end{array}$ & $\begin{array}{c}\text { The possibility } \\
\text { of event }\end{array}$ \\
\hline 1 & 30 & 11 & $54,627,300$ & 21 & $14,307,150$ \\
\hline 2 & 435 & 12 & $86,493,225$ & 22 & $5,852,925$ \\
\hline 3 & 4.060 & 13 & $119,759,850$ & 23 & $2,035,800$ \\
\hline 4 & 27,405 & 14 & $145,422,675$ & 24 & 593,775 \\
\hline 5 & 142,506 & 15 & $155,117,520$ & 25 & 142,506 \\
\hline 6 & 593.775 & 16 & $145,422,675$ & 26 & 27,405 \\
\hline 7 & $2,035,800$ & 17 & $119,759,850$ & 27 & 4,060 \\
\hline 8 & $5,852,925$ & 18 & $86,493,225$ & 28 & 435 \\
\hline 9 & $14,307,150$ & 19 & $54,627,300$ & 29 & 30 \\
\hline 10 & $30,045,015$ & 20 & $30,045,015$ & 30 & 1 \\
\hline
\end{tabular}

B. Rainfall depth and the possibility of event

Table- IV presents the amount of rainfall days and the Table- IV The amount of rainfall days and the possibility of event

\begin{tabular}{|c|l|c|}
\hline $\begin{array}{c}\text { Rainfall } \\
\text { day }\end{array}$ & The possibility of event & Value \\
\hline 1 & 30 & 30 \\
\hline 2 & $30 \times(30-1) / 2$ & 435 \\
\hline 3 & $30 \times(30-1) / 2 \times(30-2) / 3$ & 4,060 \\
\hline 4 & $30 \times(30-1) / 2 \times(30-2) / 3 \times(30-3) / 4$ & 27,405 \\
\hline 5 & $30 \times(30-1) / 2 \times(30-2) / 3 \times(30-3) / 4 \times(30-4) / 5$ & 142,506 \\
\hline 6 & $30 \times(30-1) / 2 \times(30-2) / 3 \times(30-3) / 4 \times(30-4) / 5 \times(30-5) / 6$ & 593,775 \\
\hline 7 & $30 \times(30-1) / 2 \times(30-2) / 3 \times(30-3) / 4 \times(30-4) / 5 \times(30-5) / 6 \times(30-6) / 7$ & $2.035,800$ \\
\hline. & & \\
\hline. & & \\
\hline. & & \\
\hline$n$ & $30 \times(30-1) / 2 \times(30-2) / 3 \times \ldots \ldots \ldots \ldots . . \times(30-(n-1)) / n$ & \\
\hline
\end{tabular}

If there is 3 rainfall days, so the possibility of rainfall depth that is happened is as follow:

- 3 rainfall days $>$ consumptive use of crop or

- 2 rainfall days $>$ consumptive use of crop and 1 rainfall day

$<$ consumptive use of crop

- 1 rainfall day $>$ consumptive use of crop dan 2 rainfall days $<$ consumptive use of crop

If there is happened 2 rainfall days that can be used for fulfilling the consumptive use of crop, so it will be in the range of $1 \mathrm{x}$ consumptive use of crop $+1 \mathrm{~mm}$ until $2 \mathrm{x}$ consumptive use of crop.
However, if there is happened 3 rainfall days, so the rainfall that can be used for fulfilling the consumptive use of crop will be in the range of $1 \mathrm{x}$ consumptive use of crop $+2 \mathrm{~mm}$ until 3 $\mathrm{x}$ consumptive use of crop. The rainfall that is dropped in rice fields block which can be used for fulfilling consumptive use of crop is as much as possible in amount of monthly rainfall and it will be obtained if the daily rainfall that is happened is always $\leq$ consumptive use of crop

Based on the problem above, so when there is happened the climate anomaly, 
the decreasing amount of irrigation water supply can be carried out in amount of 1 x consumptive use of crop until less than the monthly rainfall and $30 \mathrm{x}$ consumptive use of crop, depended on the amount of rainfall days and depth..

\section{The rainfall that can be used by crop}

If the amount of rainfall due to climate anomaly for the next month can be estimated by the water requirement in rice fields, the possibility of happening the rainfall days and depth, so by using the certain probability, the amount of rainfall that can be used for fulfilling consumptive use of crop can be estimated. To estimate the amount of rainfall that can be used for fulfilling consumptive use of crop, the amount of consumptive use of crop becomes as the part that is no less important. It is due to the amount of rainfall that can be used for consumptive use of crop as high as possible is in amount of the consumptive use of crop. Table- $\mathrm{V}$ presents the possibility amount of rainfall day event and depth

.Table- V. The possibility amount of rainfall day event and

\begin{tabular}{|c|c|c|c|c|c|}
\hline \multirow{2}{*}{$\begin{array}{l}\text { Rainfall } \\
\text { day in a } \\
\text { month }\end{array}$} & \multirow[t]{2}{*}{ The possibility of rainfall day event } & \multicolumn{2}{|c|}{$\begin{array}{l}\text { The range of rainfall depth that } \\
\text { can be used }\end{array}$} & \multirow{2}{*}{$\begin{array}{c}\text { The } \\
\text { possibility } \\
\text { of rainfall } \\
\text { depth } \\
\text { event } \\
\left(\mathrm{K}_{\mathrm{ch}}\right)\end{array}$} & \multirow[t]{2}{*}{$\begin{array}{c}\text { The possibility of rainfall event and } \\
\text { depth }\end{array}$} \\
\hline & & Maximum & Minimum & & \\
\hline (1) & (2) & (3) & (4) & (5) & $(6)=(2) \times(5)$ \\
\hline 1 & 30 & $\mathrm{q}$ & $\mathrm{q}$ & 1 & 30 \\
\hline 2 & 435 & 2 q Max CH month & $q+1$ & $\mathrm{q}$ & $435 q$ \\
\hline 3 & 4,060 & 3 q Max. CH month & $q+2$ & $2 q-1$ & $4,060 \times(2 q-1)$ \\
\hline 4 & 27,405 & 4 q Max. CH month & $q+3$ & $3 q-2$ & $27,405 \times(3 q-2)$ \\
\hline 5 & 142,506 & 5 q Max CH month & $q+4$ & $4 q-3$ & $142,506 \times(4 q-3)$ \\
\hline 6 & 593,775 & 6 q Max. CH Bln & $q+5$ & $5 q-4$ & $593,775 \times(5 q-4)$ \\
\hline 7 & $2,035,800$ & 7 q Max CH month & $q+6$ & $6 q-5$ & $2,035,800 \times(6 q-5)$ \\
\hline 8 & $5,852,925$ & 8 q Max. CH month & $q+7$ & $7 q-6$ & $5,852,925 \times(7 q-6)$ \\
\hline 9 & $14,307,150$ & 9 q Max CH month & $q+8$ & $8 q-7$ & $14,307,150 \times(8 q-7)$ \\
\hline 10 & $30,045,015$ & 10 q Max CH month & $q+9$ & $9 q-8$ & $30,045,015 \times(9 q-8)$ \\
\hline 11 & $54,627,300$ & 11 q Max CH month & $q+10$ & $10 q-9$ & $54,627,300 \times(10 q-9)$ \\
\hline 12 & $86,493,225$ & 12 q Max CH month & $q+11$ & $11 q-10$ & $86,493,225 \times(11 q-10)$ \\
\hline 13 & $119,759,850$ & 13 q Max CH month & $q+12$ & $12 q-11$ & $119,759,850 \times(12 q-11)$ \\
\hline 14 & $145,422,675$ & 14 q Max. CH month & $q+13$ & $13 q-12$ & $145,422,675 \times(13 q-12)$ \\
\hline 15 & $155,117,520$ & 15 q Max. CH month & $q+14$ & $14 q-13$ & $155,117,520 \times(14 q-13)$ \\
\hline 16 & $145,422,675$ & 16 q Max CH month & $q+15$ & $15 q-14$ & $145,422,675 \times(15 q-14)$ \\
\hline 17 & $119,759,850$ & 17 q Max CH month & $q+16$ & $16 q-15$ & $119,759,850 \times(16 q-15)$ \\
\hline 18 & $86,493,225$ & 18 q Max CH month & $q+17$ & $17 q-16$ & $86,493,225 \times(17 q-16)$ \\
\hline 19 & $54,627,300$ & 19 q Max CH month & $q+18$ & $18 q-17$ & $54,627,300 \times(18 q-17)$ \\
\hline 20 & $30,045,015$ & 20 q Max CH month & $q+19$ & $19 q-18$ & $30,045,015 \times(19 q-18)$ \\
\hline 21 & $14,307,150$ & 21 q Max CH month & $q+20$ & $20 q-19$ & $14,307,150 \times(20 q-19)$ \\
\hline 22 & $5,852,925$ & 22 q Max CH month & $q+21$ & $21 q-20$ & $5,852,925 \times(21 q-20)$ \\
\hline 23 & $2,035,800$ & 23 q Max CH month & $q+22$ & $22 q-21$ & $2,035,800 \times(22 q-21)$ \\
\hline 24 & 593,775 & 24 q Max CH month & $q+23$ & $23 q-22$ & $593,775 \times(23 q-22)$ \\
\hline 25 & 142,506 & 25 q Max CH month & $q+24$ & $24 q-23$ & $142,506 \times(24 q-23)$ \\
\hline 26 & 27,405 & 26 q Max CH month & $q+25$ & $q 5 q-24$ & $27,405 \times(q 5 q-24)$ \\
\hline 27 & 4,060 & 27 q Max CH month & $q+26$ & $26 q-25$ & $4,060 \times(26 q-25)$ \\
\hline 28 & 435 & 28 q Max CH month & $q+27$ & $27 q-26$ & $435 \times(27 q-26)$ \\
\hline 29 & 30 & 29 q Max CH month & $q+28$ & $28 q-27$ & $30 \times(28 q-27)$ \\
\hline 30 & 1 & 30 q Max CH month & $q+29$ & $29 q-28$ & $1 \times(29 q-28)$ \\
\hline Total & $1,073,741,823$ & & & & $15,032,385,537 q-13,958,643,714$ \\
\hline
\end{tabular}




\section{Expansion of Irrigation Area Due to the Extreme Rainfall}

\section{Consumptive use of crop when the rainfall is high due to the climate anomaly}

If the rainfall that can be used for crop with the probability of $80 \%$ can be determined, the consumptive use of crop when the climate anomaly (high rainfall) can be determined. Rainfall with the success probability of $80 \%$ is as the decreasing of irrigation water supply that can be carried out during 1 month.

\section{E. Crop area}

The difference of inflow and crop consumptive use on the normal year and the year with climate anomaly can be used for expanding the crop area. Paddy needs time and land preparation stage until harvesting during 3 until 4 months. The accuracy of estimating the next month rainfall on 3 until 4 months becomes as the very important part in making the effort to use rainfall. The effect of climate anomaly in Indonesia is only limited on dry season [14] that is May October and the first cropping season and usually is carried out on November - March and the second cropping season is carried out on March - July, so it can be confirmed that the climate anomaly will affect the second cropping season.

In many cases, although the supply of irrigation water demand for a service area is come from the reservoir, however, by the limitation of water availability on the second cropping season, not all of the area can carry out cropping. It indicates that there is the possibility to increase the crop area on the second crop season. By using the F.J. Mock model and the long enough data of rainfall, discharge, and climate, so the coefficient of infiltration and recession for a watershed can be obtained. The two coefficients are as the base in estimating the discharge. The analysis is carried out in the beginning that is estimated the extreme rainfall (the end of April). If $V_{0}$ is as the water that is saved in soil on March (it is obtained from the analysis some months before with the F.J. Mock model), $\Delta \mathrm{S}_{1}$ is the net rainfall on April and $\Delta \mathrm{S}_{2}$ is as the net rainfall estimation on May, so the inflow on May $\left(Q_{2}\right)$ can be estimated as follow:

If $\mathrm{F}=1 / 2 \times(1+\mathrm{k}) \mathrm{x} \mathrm{i}$

$$
\mathrm{Q}_{2}=(1-\mathrm{F}) \times \Delta \mathrm{S}_{2}+(1-\mathrm{k}) \times \mathrm{F} \times \Delta \mathrm{S}_{1}+(1-\mathrm{k}) \mathrm{k} \times \mathrm{V}_{0}
$$

Table- VI and VII present the supporting steps for analysis the crop area.

Table- VI, Supporting-1 for analysis the crop area

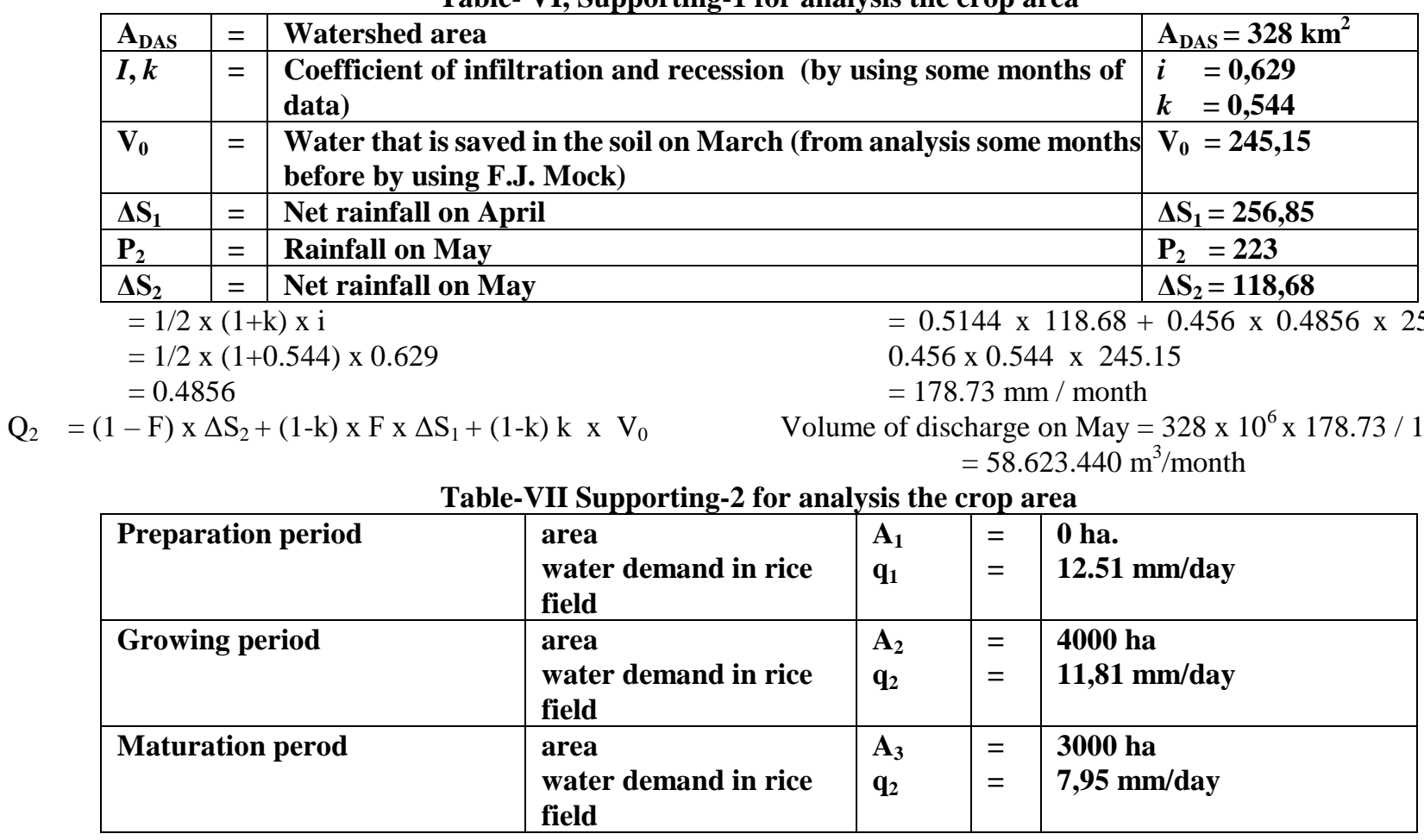

Based on the table above, by entering the estimation of rainfall on May $\left(\mathrm{P}_{2}\right)$ in amount of $223 \mathrm{~mm}$ and water demand in rice fields on the same month is $\mathrm{q}_{1}=12.51 \mathrm{~mm} / \mathrm{day}$, so it will be obtained the rainfall that can be used for crop in amount of $57.40 \mathrm{~mm} / \mathrm{month}$ with the success probability of $80 \%$. By the same way, it can be obtained the $\mathrm{q}_{2}$ and $\mathrm{q}_{3}$.

\section{CONCLUSION}

Based on the analysis as above, it can be concluded the expansion of irrigation area as presented in the Table- VIII 
Table-VIII Expansion of irrigation area

\begin{tabular}{|c|c|c|}
\hline $\begin{array}{l}P_{2} \text { on } M a y= \\
223 \mathrm{~mm} / \text { month }\end{array}$ & $\begin{array}{l}\mathrm{q}_{1}=12.51 \mathrm{~mm} / \text { day } \\
\mathrm{A}_{1}=0 \text { ha. }\end{array}$ & $\begin{array}{l}\mathrm{CH}_{\mathrm{m}}=57.40 \mathrm{~mm} / \mathrm{month} \\
\text { Vol.= } 0 \mathrm{~m}^{3} / \mathrm{month}\end{array}$ \\
\hline & $\begin{array}{l}\mathrm{q}_{2}=11.81 \mathrm{~mm} / \mathrm{day} \\
\mathrm{A}_{2}=4,000 \mathrm{ha}\end{array}$ & $\begin{array}{l}\mathrm{CH}_{\mathrm{m}}=55.00 \mathrm{~mm} / \mathrm{month} \\
\text { Vol.= 2,200,000 } \mathrm{m}^{3} / \mathrm{month}\end{array}$ \\
\hline & $\begin{array}{l}\mathrm{q}_{3}=7.95 \mathrm{~mm} / \text { day } \\
\mathrm{A}_{3}=3,000 \text { ha. }\end{array}$ & $\begin{array}{l}\mathrm{CH}_{\mathrm{m}}=40.61 \mathrm{~mm} / \mathrm{month}^{3} \\
\text { Vol.= 1,624,400 } \mathrm{m}^{3} / \mathrm{month}\end{array}$ \\
\hline
\end{tabular}

So, the volume of discharge that can be used for increasing the crop on May is in amount of: $58.623 .440+2.200 .000+$ 1.624.400 - Qdependable $_{\text {May }}$

\section{REFERENCES}

1. L.M. Limantara, D. Priyantoro, L. Prasetyorini, and R. Darmawan. "Design of Stilling Basin for Decreasing Back Water in the Dam Foot", International Journal of Geomate. ISSN 2186-2982, Vol. 15 Issue 51, 2018, p. 98-105.

2. L.M. Limantara , "The Limiting Physical Parameters of Synthetic Unit Hydrograph", World Applied Sciences Journal, Vol 7(6), 2009: 802-804

3. L.M. Limantara, "Evaluation of Roughness Constant of River in Synthetic Unit Hydrograph”. World Applied Sciences Journal, Vol. 7(9), 2009: $1209-1211$

4. D. Priyantoro and L.M. Limantara L.M.. "Conformity evaluation of synthetic unit hydrograph (case study at upstream Brantas sub-watershed, East Java Province of Indonesia", Journal of Water and Land Development. No. 35, 2017, p. 173-183. DOI: 10.1515/jwld-2017-0082

5. J.H. Song, S.M. ASCE, M.S. Kang; I.H. Song; and S.M. Jun, "Water Balance in Irrigation Reservoirs Considering Flood Control and Irrigation Efficiency Variation", Journal Irrigation and Drainage Engineering, 2016, 142(4): 04016003

6. M.H. Ahmadi, B. Omid, and H.A. Loáiciga, "Adaptive Reservoir Operation Rules Under Climatic Change", Jurnal Water Resources Management, 29, 2015:1247-1266

7. R. Afzali, S.J. Mousavi, and A. Chaheri, "Reliability-based simulation-optimization model for multi reservoir hydropower systems operations: Khersan experience", Journal of Water Resources Planning and Management. Vol. 134(1), 2008, page 24-33.

8. G. Uysal, A. Şensoy, A. Şorman, T. Akgün, and T. Gezgin, "Basin/Reservoir System Integration for Real Time Reservoir Operation", Journal Water Resources Management, 2016, 30:1653-1668

9. H.I. Eum, A. Vasan, Simonovic, and P. Slobodan, Integrated Reservoir Management System for Flood Risk Assessment Under Climate Change, Jurnal Water Resources Management, 2012, 26:3785-3802

10. R.M.W.T. Purwandaru. "Memahami La Nina, Dampaknya bagi Produksi Tanaman Pangan, dan Adaptasinya”, Surakarta, 2016.

11. L.M. Limantara, "Rekayasa Hidrologi (Engineering Hydrology", Penerbit Andi, Yogyakarta, 2019.

12. C.D. Soemarto, "Hidrologi Teknik (Engineering Hydrology)", Usaha Nasional Surabaya, 1986

13. S. Sosrodarsono and K. Takeda, Hidrologi Untuk Pengairan (Hydrology for Water Resources)", Pradnya Paramita, Jakarta, 1976

14. E. Aldrian, "Meteorologi Laut Indonesia, Badan Meteorologi dan Geofisika", Jakarta, 2008

\section{AUTHORS PROFILE}

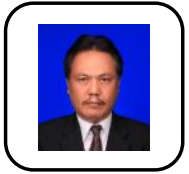

Rusdi Efendi, Doctoral Program in Department of Civil Engineering, Faculty of Engineering, University of Brawijaya, Malang, Indonesia.

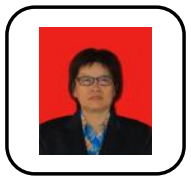

Lily Montarcih Limantara. Department of Water Resources, Faculty of Engineering, University of Brawijaya, malang, INDONESIA.

Widandi Soetopo. Department of Water Resources, Faculty of Engineering, University of Brawijaya, malang, INDONESIA.
Ery Suhartanto. Department of Water Resources, Faculty of Engineering, University of Brawijaya, malang, INDONESIA 